This is the peer reviewed version of the following article: López-Goni, J. J., Fernández-Montalvo, J., Menéndez, J. C., Yudego, F., García, A. R. and Esarte, S. (2011), Employment integration after therapeutic community treatment: a case study from Spain. International Journal of Social Welfare, 20: 292-297. doi:10.1111/j.1468-2397.2009.00687.x, which has been published in final form at https://doi.org/10.1111/j.1468-2397.2009.00687.x. This article may be used for noncommercial purposes in accordance with Wiley Terms and Conditions for SelfArchiving.

\title{
Employment integration after therapeutic community treatment: a case study from Spain
}

José Javier López-Goni ${ }^{1}$, Javier Fernández-Montalvo ${ }^{1}$, Juan Carlos Menéndez ${ }^{2}$ Fausto Yudego ${ }^{3}$, Angel Rico García ${ }^{2}$, Sonia Esarte ${ }^{3}$

\footnotetext{
${ }^{1}$ Universidad Pública de Navarra, Spain

${ }^{2}$ Fundación Centro Español Solidaridad Principado de Asturias Oviedo, Spain

${ }^{3}$ Fundación Proyecto Hombre de Navarra, Spain
}

Running title: Employment integration and the therapeutic community

Key words: addictions, therapeutic community, employment integration, follow-up

Accepted for publication June 5, 2009

Correspondence to:

José Javier Lopez-Goni

Departamento de Psicología y Pedagogía

Universidad Pública de Navarra

31006 Pamplona, Spain

Tel: +34948169857

Fax: +34948169891

E-mail: josejavier.lopez@unavarra.es 
López-Goñi, J.J., Fernández-Montalvo, J., Menéndez, J.C., Yudego, F., Rico, A. y Esarte, S. (2011). Employment integration after therapeutic community treatment: an experience in Spain. International Journal of Social Welfare, 20, 292-297. http://dx.doi.org/10.1111/j.1468- 


\begin{abstract}
This article describes the employment evolution from pre- to post-treatment of 112 patients in two therapeutic communities of Proyecto Hombre (Spain). Moreover, an analysis was made using the composite scores of the EuropASI in order to evaluate the secondary outcomes in work status, beyond drug consumption. The results show that nearly half of the patients ( $46 \%$ of the sample) changed their employment status after treatment. Specifically, 78.6 per cent of the men $(\mathrm{N}=77)$ and 64.3 per cent of the women $(\mathrm{N}=9)$ were working after treatment; there were no statistically significant differences between them. Although the unemployment figures after treatment remained high, the residents were satisfied with their work integration. No statistically significant differences were observed between those who completed the treatment and those who did not. Implications of these results for further research and clinical practice are discussed.
\end{abstract}




\section{Introduction}

A therapeutic community has been defined as a service in which the patient is separated from his/her normal environment in order to acquire a different lifestyle through living with other residents and receiving a specific treatment (De Leon, 1995). The main goal after completing a therapeutic community treatment is the integration of the resident into his/her normal environment (society) without drug consumption.

In recent years, several studies have shown the efficacy of drug dependence treatment within therapeutic communities (Edelen, Miles, Osilla \& Wenzel, 2008; Fernandez-Hermida, Secades, Fernandez \& Marina, 2002; López-Goni et al., 2008; Ravndal, Vaglum \& Lauritzen, 2005; Simpson et al., 1997). According to therapeutic efficacy studies, time spent in treatment is one indicator of success. Moreover, results in these studies show that after completing the treatment programme, residents improved significantly in terms of drug consumption as well as work, health, social functioning and partner relationships. Clinical research shows that treatment of addiction produces important changes in all areas to such an extent that these are sometimes referred to as secondary outcomes (Bodin \& Romelsjö, 2007). In this sense, to be employed constitutes an additional objective of the treatment programme as well as being a good indicator of the secondary outcomes achieved by the intervention programmes.

While it seems logical that substance use and misuse impact many dimensions of employment, there is little direct evidence of consistent findings in terms of labour consequences. Contrary to common belief, a large percentage of people with a drug addiction keep their jobs (Fernandez-Montalvo et al., 2008). However, the therapeutic community treatments force residents to leave their jobs, at least for the duration of the treatment. But what happens after completing therapy? Most follow-up studies assess the job status of the patients at the pre-treatment evaluation. However, the difference 
between job status at pre-treatment and post-treatment has rarely been evaluated. Only recently have some studies evaluated the relationship between the employment situation and the treatment results in specific samples of patients (Beattie, McDaniel \& Bond, 2006; Cosden et al., 2006; Koo, Chitwood \& Sanchez, 2007; Schmidt, Zabkiewicz, Jacobs \& Wiley, 2007). Treatment-based studies of employment often conceptualise it as a desired treatment outcome, while loss of employment has been associated with relapse into drug use and dropping out of treatment (Leukefeld, Webster, Staton-Tindall \& Duvall, 2007). Studies have also focused on employment status just prior to admission to treatment as a potential predictor of in-treatment or post-treatment relapse (Koo et al., 2007).

However, there have been only a few studies of employment among out-oftreatment populations. Further research is needed i to determine the employment consequences of having received treatment a in therapeutic community. Moreover, intervention for employment and career advancement seems essential. Obtaining and sustaining full employment could be important components that facilitate re-entry into a non-drug lifestyle and cessation of use. However, reducing drug use does not guarantee post-treatment employment. Drug users may lack the necessary job skills needed to obtain employment (Dunlap, Zarkin, Lennox \& Bray, 2007); thus, intervention and treatment efforts must include employment training. Drug users who have the requisite skills and qualifications to hold higher level occupations could increase their income levels and support their transition to a conventional lifestyle (Koo et al., 2007; Leukefeld et al., 2007).

In this pilot study, we present an analysis of a sample of residents who received treatment for addiction in two therapeutic communities of Proyecto Hombre in Spain: Proyecto Hombre of Navarre and Proyecto Hombre of Asturias. The efficacy of both López-Goñi, J.J., Fernández-Montalvo, J., Menéndez, J.C., Yudego, F., Rico, A. y Esarte, S. (2011). Employment integration after therapeutic community treatment: an experience in Spain.

International Journal of Social Welfare, 20, 292-297. http://dx.doi.org/10.1111/j.1468- 
clinical centres has been the object of evaluation, and both communities have demonstrated their efficiency in the treatment of drug dependence (Fernandez-Hermida et al., 2002; Fernandez-Montalvo et al., 2008). However, in the present study, a specific analysis was made of the employment situation of residents after receiving therapeutic community treatment (out-of-treatment patients). Moreover, this topic was further analysed using the composite scores of the EuropASI (Kokkevi \& Hartgers, 1995). The final objective was to evaluate secondary outcomes in employment status, beyond drug consumption.

\section{Methods}

\section{Subjects}

The sample for this study included 112 participants admitted to the Proyecto Hombre of Navarra and Asturias Therapeutic Community programmes (Spain) in order to receive psychological treatment for drug addiction. Those selected for the sample were required to have been admitted for treatment at some time in the year 2006, be between 18 and 65 years old, have undergone treatment for at least 12 months, and have consented to participation after having been thoroughly informed about the study.

\section{Table 1 about here}

The socio-demographic characteristics of the sample are presented in Table 1. As shown in the table, it was a predominantly male population (87.5\%), the average age was 33.9 years, and the majority (60.7\%) were unmarried.

With regard to drug consumption, 31.5 per cent of the residents suffered from poly-consumption of multiple substances. In addition, 18 per cent presented simultaneous abuse of alcohol and other substances, 18 per cent abused cocaine and 
17.1 per cent abused heroin. Other substances showed lower consumption rates. Lastly, from a legal point of view, 27.7 per cent of the sample (31 residents) had pending criminal charges related to drug consumption.

Regarding the status of patient treatment, 34 cases (30.3\%) dropped out, and 78 cases (69.7\%) completed the entire treatment. Seventy-one men (72.4\%) and seven women (50\%) completed the treatment; there were no statistical differences between the groups $(\mathrm{X} 2=1.9)$.

\section{Assessment}

The EuropASI interview (Kokkevi \& Hartgers, 1995) assesses the need for treatment in the following six areas: a) general medical state; b) labour and economic situation; c) drug consumption (alcohol included); d) legal problems; e) family and social relationships; and f) psychological state. Scores ranged from 0 (no problem) to 9 (extreme problem) in each area, and the cut-off point for each area was 4. The Spanish version was used in this study (Bobes, Gónzález, Sáiz \& Bousoño, 1996).

Composite scores (CS) of the ASI were developed for research purposes; these scores measure problem severity during the last 30 days and range between $0.00-1.00$, with higher values denoting a higher degree of severity. CS are not standardised; therefore, equivalent scores in different problem areas are not indicative of equivalent degrees of problem severity. High internal consistency has been regularly reported for the alcohol, medical and psychiatric CS, while some studies have reported lower consistency coefficients for the remaining CS (Mäkelä, 2004). The short-term testretest reliability of the ASI severity ratings has been reported to be equal to or above 0.92 for all domains (McLellan et al., 1985). 
Finally, a follow-up questionnaire about employment was administered. This questionnaire, consisting of 9 questions, was specifically developed by a rational method, for the present research in order to gather data related to employment situation.

\section{Treatment}

The treatment programme comprised three therapeutic phases: reception, residential therapeutic community, and reinsertion. Reception, with an estimated duration of 1 month, is outpatient-based and aims to enhance the motivation to change and to achieve initial abstinence from both illegal drugs and alcohol. During this phase, residents take active part in encounter groups. The second phase, residential therapeutic community, has an estimated duration of 9 months. This phase is inpatient-based and aims to encourage acquisition of behaviours that increase personal independence and to resolve specific problems in order to achieve relapse prevention. During this phase, residents receive group and occupational therapy. Finally, the third phase, reinsertion, has an estimated duration of 12 months. It involves a progressive reduction in the intensity of treatment. The main aim of this phase is to achieve social, family and employment reintegration through individual and group therapy.

This therapeutic programme has been evaluated (Fernandez-Hermida et al., 2002; Fernandez-Montalvo et al., 2008), and the efficacy of the therapeutic community in the treatment of addictions and other associated factors has been demonstrated (Bodin \& Romelsjö, 2007).

\section{Procedure}

Residents in the sample were interviewed with the EuropASI at the beginning of treatment and at follow-up. The average time that elapsed from the point of leaving the 
programme until the follow-up interview was 1 year (range: 9 months-15 months). The interviews were conducted by two trained clinical psychologists and took place in locations chosen by the patients (therapeutic community, patient's home or a social service office). No monetary incentive was offered for participation in the study, and all residents gave their informed consent to participate.

\section{Data analysis}

Statistical analyses were carried out with SPSS (version 15.0 for Windows). Descriptive analyses were conducted for all variables. Bivariate analyses were employed using $\chi 2$ or t-test statistic, depending on the nature of the variables studied. A difference of $p<.05$ was considered significant.

\section{Results}

\section{Rate of employment before and after treatment}

Table 2 shows the job situation of the residents before and after completing treatment in the therapeutic community. Of the sample, 67.6 per cent $(\mathrm{N}=75)$ were working full-time when treatment began ( $72.4 \%$ of the men and $28.6 \%$ of the women); 12.5 per cent of the total sample were unemployed, but it is relevant to note that, in the case of women, this rate was a $42.9 \%$.

\section{Table 2 about here}

After completing the therapeutic programme, the percentage of residents working full-time increased to 74.1 per cent $(\mathrm{N}=83)$. Nevertheless, the percentage of unemployed also increased, to 16.1 per cent $(\mathrm{N}=18)$ and the rate of people with disability increased to 7.1 per cent $(\mathrm{N}=8)$. No statistically significant differences between pre- and post-treatment were found.

López-Goñi, J.J., Fernández-Montalvo, J., Menéndez, J.C., Yudego, F., Rico, A. y Esarte, S. (2011). Employment integration after therapeutic community treatment: an experience in Spain.

International Journal of Social Welfare, 20, 292-297. http://dx.doi.org/10.1111/j.1468- 
On the other hand, only 54 per cent of the sample $(\mathrm{N}=60)$ retained the same job standard before and after treatment. The remaining residents $(46 \% ; \mathrm{N}=52)$ changed their employment status after treatment. For example, whereas the number of people moving into full-time work increased by 8 persons, 20 individuals who had been working fulltime at the beginning of the treatment left their work. Also, 13 persons lost their jobs, 6 obtained disability benefits and 1 began working part-time.

To summarise, after treatment, 78.6 per cent of the male residents $(\mathrm{N}=77)$ and 64.3 per cent of the women ( $\mathrm{N}=9)$ were working, and no statistically significant difference was found $(\mathrm{X} 2=.7 ; \mathrm{p}=.39)$.

\section{Job satisfaction after treatment}

All the residents in the sample (112 cases) were asked about the extent of their job satisfaction after treatment. Five residents (4.9\%) considered their job situation after treatment as having worsened. Thirty-five residents (31.3\%) replied that everything remained as before, and 62 residents said their situation improved $(\mathrm{N}=31 ; 27.7 \%)$ or improved a lot $(\mathrm{N}=31 ; 27.7 \%)$.

When dichotomising these variables in order to compare subjects who improved and those who did not, no significant statistical difference between men and women was found $(\mathrm{X} 2=1.4 ; \mathrm{p}=.25)$. There were also no meaningful differences between those who completed therapy and those who dropped out $(\mathrm{X} 2=.01 ; \mathrm{p}=.98)$.

On the other hand, all the residents participated in the normal activities of the therapeutic community, working on basic habits of living together (responsibility, punctuality etc.). Only 7 persons (6.3\%) demonstrated little or no satisfaction with the practice of these activities. These results, as well as the participation of men and women and completers and dropouts, are shown in Table 3.

López-Goñi, J.J., Fernández-Montalvo, J., Menéndez, J.C., Yudego, F., Rico, A. y Esarte, S. (2011). Employment integration after therapeutic community treatment: an experience in Spain.

International Journal of Social Welfare, 20, 292-297. http://dx.doi.org/10.1111/j.1468- 


\section{Table 3 about here}

\section{Composite scores}

Finally, a follow-up comparison of the EuropAsi composite scores between the residents who worked and those who did not was carried out. Results are presented in Table 4.

Table 4 about here

People who did not work in the follow-up showed a higher degree of severity on the economic and psychological scales of EuropAsi. Moreover, those who had not been working prior to treatment also presented a higher degree of severity on the psychological scale.

\section{Discussion}

This is a follow-up study conducted on a relatively large sample of residents from two therapeutic communities of the Association Proyecto Hombre in Spain. In this research, employment status after treatment and a comparison of these data with the residents' initial situation were specifically studied. In addition, residents were asked about their degree of satisfaction with the treatment.

Results showed that almost half of the sample (46\%; $N=52$ ) changed their employment status after treatment. Two important reasons for this change are observed: first, 10 people who joined treatment from prison obtained full-time employment during the follow-up period, and second, after passing through the treatment programme, 11 people received social benefits (mainly, disability and unemployment benefits). These data indicate that the assisted population has to some extent been integrated into society. 
On the other hand, the unemployment figures in the study were high (even higher at the end of treatment than at the beginning). Nevertheless, residents were satisfied with their work integration. The high rate of unemployment could in part be a consequence of the treatment modality itself. Admission to a therapeutic community for receiving treatment implies a break from normal activities, one of which is work, with an increase in unemployment as a consequence. Therefore, for each case, the treatment staff should take into consideration whether admission to a therapeutic community with possible job repercussions is advisable, even though the community itself addresses this aspect in their own activities for work integration. This consideration is important because in the follow-up of the study, as has also been found in other research (Sterling et al., 2001), persons who were not employed showed a significantly higher degree of severity on the economic and psychological scales of EuropAsi. Some studies have reported, for example, that unemployed drug users who were not looking for work were more likely to develop greater mental health problems than those who were either looking for work or were employed (Johnson, Reynolds \& Fisher, 2001).

No statistically significant differences were observed between those who completed the treatment and those who abandoned it prematurely. Perhaps this is related to the fact that all residents remained in the programme for at least 12 months. It is likely that the treatment has positive effects, even if it is not completed.

Nevertheless, this study has some limitations. One issue that should be taken into account is the configuration of the sample itself. It is noteworthy that few women were included in the sample; therefore, the obtained results concern mainly male addiction patients. It is true that this is the case in almost all studies on drug dependence (Fernandez-Montalvo, Landa, Lopez-Goni, \& Lorea, 2006; Fernandez-Montalvo et al., 2008; Lopez-Goni et al., 2008), but it should nevertheless be taken into account when 
generalising the findings. Another limitation is that all residents in the sample had been in treatment for nearly a year, including those who had abandoned the programme before conclusion. It is likely that an evaluation of persons who dropped out the programme much earlier would have resulted in different findings. Further research is, therefore, required to determine the needs of this population.

This is a pilot study on employment situation in addicted patients after moving through a therapeutic community treatment. Further research is needed in order to determine the employment consequences of receiving treatment in therapeutic communities.

\section{Acknowledgments}

This study was supported by grants from the European Social Fund-Foundation Luis

Vives, the Fundacion Proyecto Hombre de Navarre, and the Fundación Centro Español de Solidaridad Principado de Asturias.

\section{References}

Beattie M, McDaniel P, Bond J (2006). Public sector managed care: a comparative evaluation of substance abuse treatment in three counties. Addiction 101(6): 857-872.

Bobes J, Gónzález MP, Sáiz PA, Bousoño M (1996). Índice europeo de severidad de la adicción: EuropASI. Versión española [EuropASI. Spanish version]. Paper presented at the Actas de la IV Reunión Interregional de Psiquiatría.

Bodin MC, Romelsjö A (2007). Secondary outcomes: Group and individual change and relationships to drinking outcomes. Addiction Research \& Theory 15: 587-599. 
Cosden M, Basch JE, Campos E, Greenwell A, Barazani S, Walker S (2006). Effects of motivation and problem severity on court-based drug treatment. Crime \& Delinquency 52(4): 599-618.

De Leon G (1995). Therapeutic Communities for Addictions: a theoretical framework. International Journal of the Addictions 30: 1603-1645.

Dunlap LJ, Zarkin GA, Lennox R, Bray JW. (2007). Do Treatment Services for Drug Users in Outpatient Drug-Free Treatment Programs Affect Employment and Crime? Substance Use \& Misuse 42(7): 1161-1185.

Edelen MA, Miles JNV, Osilla KC, Wenzel SL (2008). Further validity evidence for the Dimensions of Change in therapeutic community treatment instrument. American Journal of Drug and Alcohol Abuse 34(3): 285-292.

Fernandez-Hermida JR, Secades R, Fernandez JJ, Marina PA (2002). Effectiveness of a therapeutic community treatment in Spain: A long-term follow-up study. European Addiction Research 8(1): 22-29.

Fernandez-Montalvo, J., Landa, N., Lopez-Goni, J. J., \& Lorea, I. (2006). Personality disorders in alcoholics: A comparative pilot study between the IPDE and the MCMIII. Addictive Behavior, 31(8), 1442-1448.

Fernandez-Montalvo, J., Lopez-Goni, J. J., Illescas, C., Landa, N., \& Lorea, I. (2008). Evaluation of a therapeutic community treatment program: A long-term follow-up study in Spain. Substance Use \& Misuse 43(10), 1362-1377.

Johnson ME, Reynolds GL, Fisher DG (2001). Employment status and psychological symptomatology among drug users not currently in treatment. Evaluation and Programming Planning 24: 215-220.

Kokkevi A, Hartgers C (1995). European adaptation of a multidimensional assessment instrument for drug and alcohol dependence. European Addiction Research 1: $208-210$.

Koo DJ, Chitwood DD, Sanchez J (2007). Factors for Employment: A Case-Control Study of Fully Employed and Unemployed Heroin Users. Substance Use \& Misuse 42(7): 1035-1054.

Leukefeld C, Webster JM, Staton-Tindall M, Duvall J (2007). Employment and Work Among Drug Court Clients: 12-Month Outcomes. Substance Use \& Misuse 42(7): 1109-1126.

López-Goñi, J.J., Fernández-Montalvo, J., Menéndez, J.C., Yudego, F., Rico, A. y Esarte, S. (2011). Employment integration after therapeutic community treatment: an experience in Spain.

International Journal of Social Welfare, 20, 292-297. http://dx.doi.org/10.1111/j.14682397.2009.00687.x 
Lopez-Goni, J. J., Fernandez- Montalvo, J., Illescas, C., Landa, N., \& Lorea, I. (2008).

Determining socio-demographic predictors of treatment dropout: results in a therapeutic community. International Journal of Social Welfare, 17(374-378).

Mäkelä K (2004). Studies of the reliability and validity of the Addiction Severity Index. Addiction Research \& Theory 99: 398-410.

McLellan AT, Luborsky L, Cacciola J, Griffith J, Evans F, Barr HL, et al. (1985). New data from the Addiction Severity Index. Reliability and validity in three centers. The Journal of Nervous and Mental Disease 173: 412-423.

Ravndal E, Vaglum P, Lauritzen G (2005). Completion of long-term inpatient treatment of drug abusers: A prospective study from 13 different units. European Addiction Research 11(4): 180-185.

Schmidt L, Zabkiewicz D, Jacobs L, Wiley J (2007). Substance Abuse and Employment Among Welfare Mothers: From Welfare to Work and Back Again? Substance Use \& Misuse 42(7): 1069-1087.

Simpson DD, Joe GW, Broome KM, Hiller ML, Knight Rowan-Szal GA (1997).

Program diversity and treatment retention rates in the Drug Abuse Treatment Outcome Study (DATOS). Psychology of Addictive Behaviors 11: 279-293.

Sterling RC, Gottheil E, Glassman SD, Weinstein SP, Serota RD, Lunday A (2001). Correlates of employment: A cohort study. The American Journal of Drug and Alcohol Abuse 27: 137-146.

López-Goñi, J.J., Fernández-Montalvo, J., Menéndez, J.C., Yudego, F., Rico, A. y Esarte, S. (2011). Employment integration after therapeutic community treatment: an experience in Spain.

International Journal of Social Welfare, 20, 292-297. http://dx.doi.org/10.1111/j.1468- 
Table 1. Socio-demographic characteristics of the sample $(\mathrm{N}=112)$.

\begin{tabular}{|c|c|c|c|c|c|c|}
\hline VARIABLES & & $\begin{array}{l}\text { Men } \\
\text { v = 98) } \\
\operatorname{lan}(\text { SD) }\end{array}$ & \multicolumn{2}{|c|}{$\begin{array}{c}\text { Women } \\
(\mathrm{N}=14) \\
\text { Mean (SD) }\end{array}$} & \multicolumn{2}{|c|}{$\begin{array}{c}\text { Total } \\
(\mathrm{N}=112) \\
\text { Mean (SD) }\end{array}$} \\
\hline Age & 34.1 & $(7.20)$ & 32.5 & $(7.2)$ & 33.9 & $(7.2)$ \\
\hline VARIABLES & $\mathbf{N}$ & (\%) & $\mathbf{N}$ & $(\%)$ & $\mathbf{N}$ & (\%) \\
\hline $\begin{array}{l}\text { Legal } \\
\text { On parole/probation } \\
\text { Admission prompted by justice system } \\
\text { Awaiting charges/trial/sentence } \\
\end{array}$ & $\begin{array}{c}8 \\
19 \\
26 \\
\end{array}$ & $\begin{array}{c}(8.2 \%) \\
(19.4 \%) \\
(26.5 \%)\end{array}$ & $\begin{array}{l}1 \\
0 \\
5\end{array}$ & $\begin{array}{c}(7.1 \%) \\
0 \\
(35.7 \%)\end{array}$ & $\begin{array}{c}9 \\
19 \\
31 \\
\end{array}$ & $\begin{array}{c}(8.0 \%) \\
(17.0 \%) \\
(27.7 \%)\end{array}$ \\
\hline $\begin{array}{l}\quad \text { Current marital status } \\
\text { Married or remarried } \\
\text { Separated or divorced } \\
\text { Never married }\end{array}$ & $\begin{array}{l}18 \\
21 \\
59 \\
\end{array}$ & $\begin{array}{l}(18.4 \%) \\
(21.4 \%) \\
(60.2 \%)\end{array}$ & $\begin{array}{l}2 \\
3 \\
9 \\
\end{array}$ & $\begin{array}{l}(14.3 \%) \\
(21.4 \%) \\
(64.3 \%)\end{array}$ & $\begin{array}{l}20 \\
24 \\
68 \\
\end{array}$ & $\begin{array}{l}(17.8 \%) \\
(21.4 \%) \\
(60.7 \%)\end{array}$ \\
\hline $\begin{array}{l}\text { Usual living arrangements (past } 3 \text { years) } \\
\text { Living with partner and children } \\
\text { Living with partner } \\
\text { Living alone } \\
\text { Living with children only } \\
\text { Living with friends/roommates } \\
\text { Living with parents or family } \\
\text { Protected environment } \\
\text { No stable living arrangement }\end{array}$ & $\begin{array}{l}18 \\
22 \\
8 \\
2 \\
2 \\
27 \\
12 \\
6\end{array}$ & $\begin{array}{l}(18.4 \%) \\
(22.4 \%) \\
(8.2 \%) \\
(2.0 \%) \\
(2.0 \%) \\
(27.5 \%) \\
(12.2 \%) \\
(6.1 \%) \\
\end{array}$ & $\begin{array}{l}0 \\
7 \\
0 \\
0 \\
2 \\
4 \\
0 \\
1\end{array}$ & $\begin{array}{c}0 \\
(50.0 \%) \\
0 \\
0 \\
(14.3 \%) \\
(28.6 \%) \\
0 \\
(7.1 \%) \\
\end{array}$ & $\begin{array}{c}18 \\
29 \\
8 \\
2 \\
4 \\
31 \\
12 \\
7 \\
\end{array}$ & $\begin{array}{l}(16.0 \%) \\
(25.9 \%) \\
(7.1 \%) \\
(1.8 \%) \\
(3.6 \%) \\
(27.7 \%) \\
(10.7 \%) \\
(6.2 \%)\end{array}$ \\
\hline $\begin{array}{l}\text { Substance that motivated treatment } \\
\text { Alcohol } \\
\text { Heroin } \\
\text { Cocaine } \\
\text { Cannabis } \\
\text { Hallucinogens } \\
\text { Alcohol and other drugs } \\
\text { Poly-consumption }\end{array}$ & $\begin{array}{c}13 \\
15 \\
18 \\
1 \\
1 \\
17 \\
32 \\
\end{array}$ & $\begin{array}{c}(13.4 \%) \\
(15.5 \%) \\
(18.6 \%) \\
(1.0 \%) \\
(1.0 \%) \\
(17.5 \%) \\
(33.0 \%)\end{array}$ & $\begin{array}{l}2 \\
4 \\
2 \\
0 \\
0 \\
3 \\
3 \\
\end{array}$ & $\begin{array}{c}(14.2 \%) \\
(28.6 \%) \\
(14.3 \%) \\
0.0 \\
0.0 \\
(21.4 \%) \\
(21.4 \%)\end{array}$ & $\begin{array}{c}15 \\
19 \\
20 \\
1 \\
1 \\
20 \\
35 \\
\end{array}$ & $\begin{array}{c}(13.5 \%) \\
(17.1 \%) \\
(18.0 \%) \\
(0.9 \%) \\
(0.9 \%) \\
(18.0 \%) \\
(31.5 \%)\end{array}$ \\
\hline
\end{tabular}

López-Goñi, J.J., Fernández-Montalvo, J., Menéndez, J.C., Yudego, F., Rico, A. y Esarte, S. (2011). Employment integration after therapeutic community treatment: an experience in Spain.

International Journal of Social Welfare, 20, 292-297. http://dx.doi.org/10.1111/j.1468- 
Table 2. Rate of employment before and after treatment.

\begin{tabular}{|c|c|c|c|c|c|c|c|c|c|c|c|c|}
\hline & \multicolumn{4}{|c|}{$\begin{array}{c}\text { Male } \\
(\mathrm{N}=98)\end{array}$} & \multicolumn{4}{|c|}{$\begin{array}{l}\text { Female } \\
(\mathrm{N}=14)\end{array}$} & \multicolumn{4}{|c|}{$\begin{array}{c}\text { Total } \\
(\mathrm{N}=112)\end{array}$} \\
\hline & \multicolumn{2}{|c|}{ Start } & \multicolumn{2}{|c|}{ Follow up } & \multicolumn{2}{|c|}{ Start } & \multicolumn{2}{|c|}{ Follow up } & \multicolumn{2}{|c|}{ Start } & \multicolumn{2}{|c|}{ Follow up } \\
\hline & $\mathbf{N}$ & $\%$ & $\mathbf{N}$ & $\%$ & $\mathbf{N}$ & $\%$ & $\mathbf{N}$ & $\%$ & $\mathbf{N}$ & $\%$ & $\mathbf{N}$ & $\%$ \\
\hline $\begin{array}{l}\text { Usual employment pattern } \\
\text { (last } 3 \text { years) }\end{array}$ & & & & & & & & & & & & \\
\hline Full-time & 71 & 72.4 & 76 & 77.6 & 4 & 28.6 & 7 & 50.0 & 75 & 67.6 & 83 & 74.1 \\
\hline Partial-time & 6 & 6.1 & 1 & 1.0 & 4 & 28.6 & 2 & 14.3 & 10 & 9.0 & 3 & 2.7 \\
\hline Student & 1 & 1 & 0 & 0 & 0 & 0 & 0 & 0 & 1 & 0.9 & 0 & 0 \\
\hline Retirement/disability & 1 & 1 & 8 & 8.2 & 0 & 0 & 0 & 0 & 1 & 0.9 & 8 & 7.1 \\
\hline Unemployed (includes housewives) & 8 & 8.2 & 13 & 13.3 & 6 & 42.9 & 5 & 35.7 & 14 & 12.5 & 18 & 16.1 \\
\hline Protected environment & 11 & 11.2 & 0 & 0 & 0 & 0 & 0 & 0 & 11 & 9.9 & 0 & 0 \\
\hline
\end{tabular}

López-Goñi, J.J., Fernández-Montalvo, J., Menéndez, J.C., Yudego, F., Rico, A. y Esarte, S. (2011). Employment integration after therapeutic community treatment: an experience in Spain.

International Journal of Social Welfare, 20, 292-297. http://dx.doi.org/10.1111/j.1468- 
Table 3. Satisfaction with the practice of work abilities in the therapeutic community.

\begin{tabular}{lrrrrrrrrrr} 
& \multicolumn{1}{c}{ Men } & \multicolumn{1}{c}{ Women } & \multicolumn{2}{c}{ Total } & \multicolumn{3}{c}{ Dropouts } & \multicolumn{2}{c}{ Completers } \\
\hline & $\mathbf{N}$ & $\mathbf{\%}$ & $\mathbf{N}$ & $\mathbf{\%}$ & $\boldsymbol{N}$ & $\boldsymbol{\%}$ & $\mathbf{N}$ & $\mathbf{\%}$ & $\mathbf{N}$ & $\mathbf{\%}$ \\
\hline Very satisfied & 42 & 42.9 & 6 & 42.9 & 48 & 42.9 & 13 & 38.2 & 35 & 44.9 \\
Quite satisfied & 23 & 23.5 & 2 & 14.3 & 25 & 22.3 & 9 & 26.5 & 16 & 20.5 \\
Satisfied & 27 & 27.6 & 5 & 35.7 & 32 & 28.6 & 8 & 23.5 & 24 & 30.8 \\
Little satisfied & 5 & 5.1 & 0 & 0.0 & 5 & 4.5 & 3 & 8.8 & 2 & 2.6 \\
Not satisfied & 1 & 1.0 & 1 & 7.1 & 2 & 1.8 & 1 & 2.9 & 1 & 1.3 \\
Total & 98 & 100 & 14 & 100 & 112 & 100 & 34 & 100 & 78 & 100
\end{tabular}

López-Goñi, J.J., Fernández-Montalvo, J., Menéndez, J.C., Yudego, F., Rico, A. y Esarte, S. (2011). Employment integration after therapeutic community treatment: an experience in Spain. International Journal of Social Welfare, 20, 292-297. http://dx.doi.org/10.1111/j.1468- 
Table 4. Differences between those who worked and those who did not (composite scores) at follow-up.

\begin{tabular}{|l|l|l|l|l|l|l|r|r|r|}
\hline & & \multicolumn{5}{|c|}{ Before } & \multicolumn{3}{c|}{ After } \\
\hline \multirow{2}{*}{ Medical } & & N & Mean & SD & t & N & Mean & SD & \multicolumn{1}{c|}{ t } \\
& No job & 26 & .36 & .29 & 1.15 & 26 & .33 & .28 & .85 \\
& Worked & 86 & .29 & .26 & & 86 & .28 & .24 & \\
\hline Economic & No job & 25 & .77 & .34 & .12 & 26 & .94 & .20 & $14.3^{* *}$ \\
& Worked & 79 & .76 & .37 & & 86 & .16 & .34 & \\
\hline Job satisfaction & No job & 25 & .39 & .27 & .022 & 26 & .28 & .29 & .79 \\
& Worked & 83 & .39 & .28 & & 86 & .24 & .28 & \\
\hline Legal & No job & 26 & .25 & .29 & .1 & 26 & .12 & .16 & .87 \\
& Worked & 86 & .25 & .27 & & 86 & .15 & .21 & \\
\hline Family & No job & 26 & .48 & .27 & .4 & 26 & .25 & .26 & .65 \\
& Worked & 83 & .46 & .23 & & 86 & .21 & .23 & \\
\hline Social & No job & 26 & .34 & .23 & 1.4 & 26 & .16 & .17 & .08 \\
& Worked & 81 & .28 & .18 & & 86 & .15 & .18 & \\
\hline Psychological & No job & 24 & .40 & .24 & $2.0 *$ & 26 & .29 & .28 & $2.1 *$ \\
& Worked & 81 & .29 & .23 & & 86 & .16 & .18 & \\
\hline
\end{tabular}

${ }^{*} \mathrm{p}<.05 ;{ }^{* *} \mathrm{p}<.01$

López-Goñi, J.J., Fernández-Montalvo, J., Menéndez, J.C., Yudego, F., Rico, A. y Esarte, S. (2011). Employment integration after therapeutic community treatment: an experience in Spain.

International Journal of Social Welfare, 20, 292-297. http://dx.doi.org/10.1111/j.1468- 